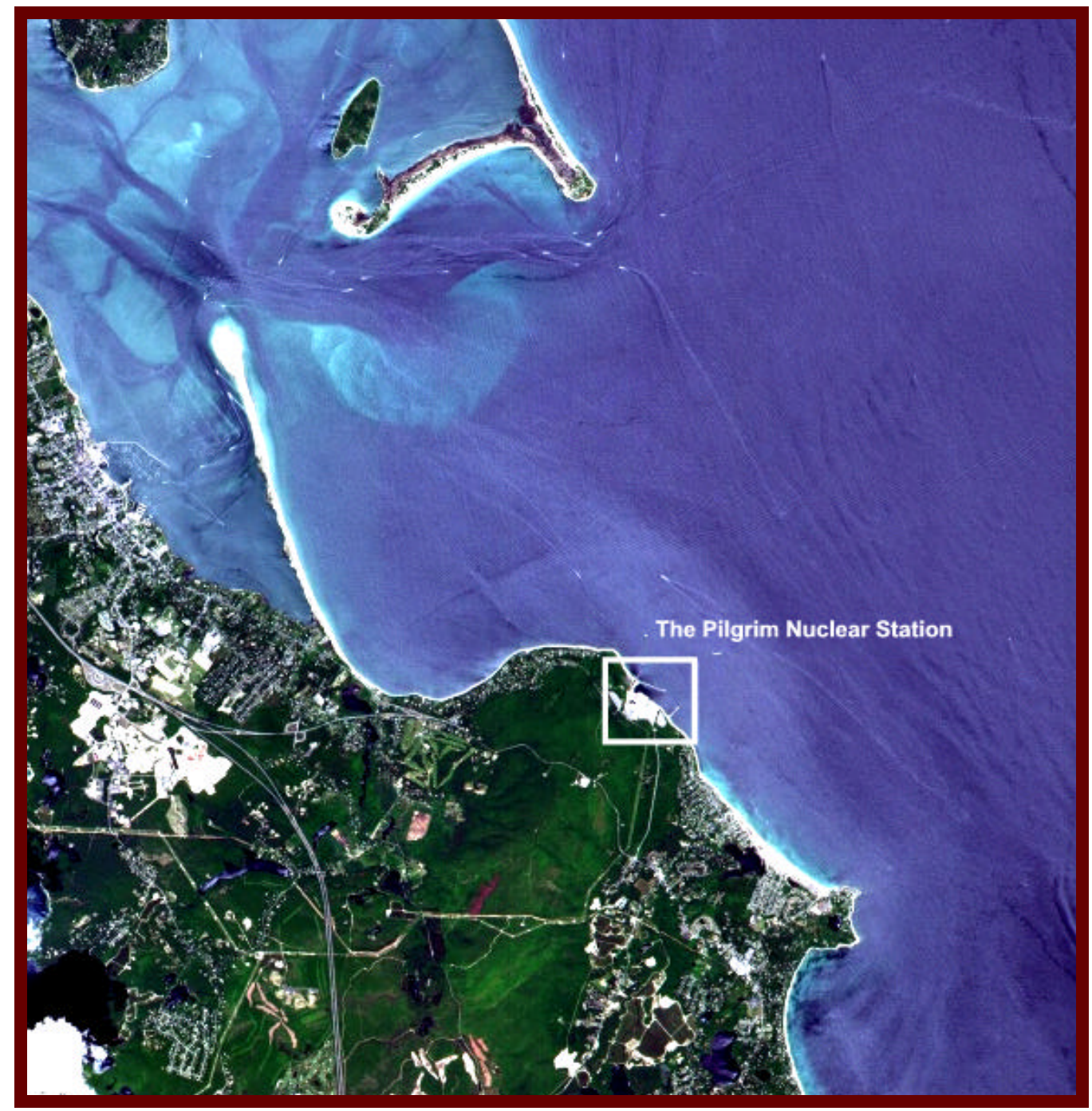

MTI true color image

\title{
Final MTI Data Report: Pilgrim Nuclear Station (U)
}

Westinghouse Savannah River Company

August 2002

Savannah River Site

Aiken, SC 29808

Prepared for the U. S. Department of Energy under contract no. DE-AC09-96SR18500

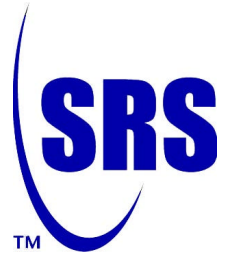


This document was prepared in conjunction with work accomplished under Contract No. DE-AC09-96SR18500 with the U. S. Department of Energy.

\section{DISCLAIMER}

This report was prepared as an account of work sponsored by an agency of the United States Government. Neither the United States Government nor any agency thereof, nor any of their employees, makes any warranty, express or implied, or assumes any legal liability or responsibility for the accuracy, completeness, or usefulness of any information, apparatus, product or process disclosed, or represents that its use would not infringe privately owned rights. Reference herein to any specific commercial product, process or service by trade name, trademark, manufacturer, or otherwise does not necessarily constitute or imply its endorsement, recommendation, or favoring by the United States Government or any agency thereof. The views and opinions of authors expressed herein do not necessarily state or reflect those of the United States Government or any agency thereof.

This report has been reproduced directly from the best available copy.

Available for sale to the public, in paper, from: U.S. Department of Commerce, National Technical Information Service, 5285 Port Royal Road, Springfield, VA 22161, phone: (800) 553-6847, fax: (703) 605-6900

email: orders@ntis.fedworld.gov

online ordering: http://www.ntis.gov/help/index.asp

Available electronically at http://www.osti.gov/bridge

Available for a processing fee to U.S. Department of Energy and its contractors, in paper, from: U.S. Department of Energy, Office of Scientific and Technical Information, P.O. Box 62, Oak Ridge, TN 37831-0062,

phone: (865)576-8401,

fax: (865)576-5728

email: $\underline{\text { reports@ adonis.osti.gov }}$ 


\title{
Final MTI Data Report: Pilgrim Nuclear Station (U)
}

\author{
Prepared by \\ Matthew J. Parker and Alfred J. Garrett \\ Nonproliferation Technologies Section \\ Savannah River Technology Center \\ Aiken, South Carolina, 29808
}

August 2002 
WSRC-TR-2002-00373

Final MTI Data Report: Pilgrim Nuclear Station (U)

Savannah River Technology Center

This page intentionally left blank. 


\section{TABLE OF CONTENTS}

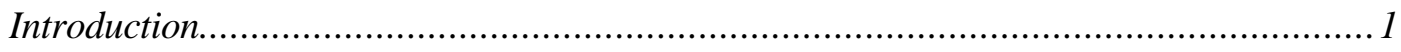

Surface Water Temperature Measurements ...................................................... 1

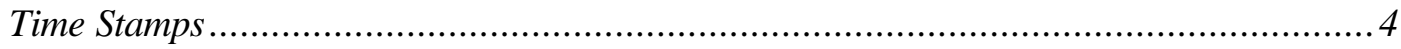

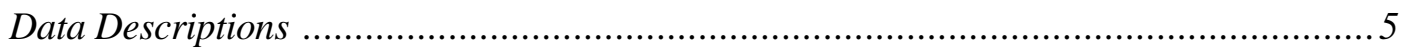

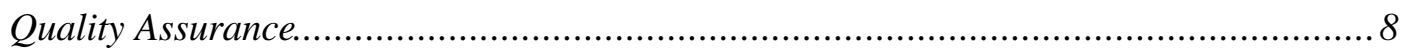

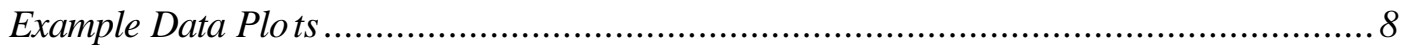

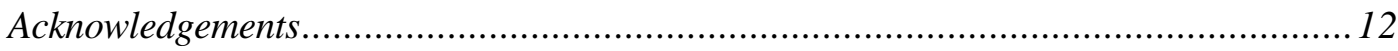

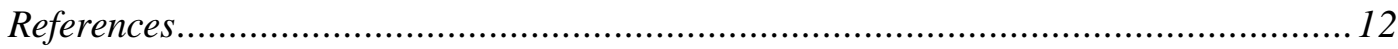

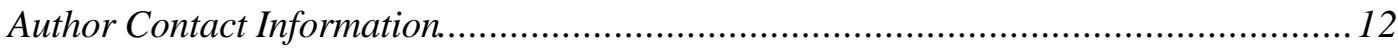

\section{LIST OF F IGURES}

Figure 1. The Pilgrim Nuclear Power Station .................................................... 1

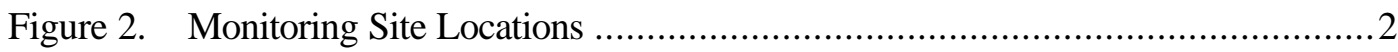

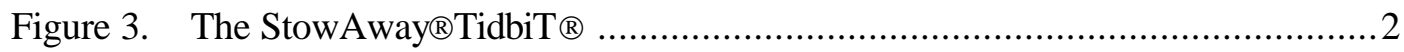

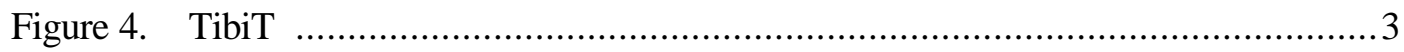

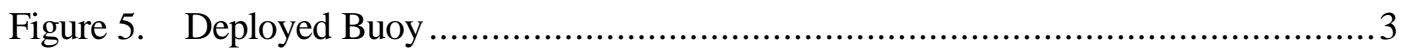

Figure 6. Time Series Plot of Water Temperatures ........................................ 8

Figure 7. Supplemental Water Temperature Measurements.................................... 9

Figure 8. Example of Wind Direction Data Collected ......................................... 9

Figure 9. Example of Wind Direction Data Collected ......................................... 10

Figure 10. Example of Air Temperature Data Collected ........................................... 10

Figure 11. Example of Plant Water Intake and Outfall Temperatures...........................11

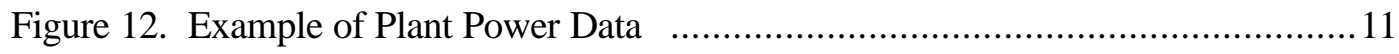


WSRC-TR-2002-00373

Final MTI Data Report: Pilgrim Nuclear Station (U)

Savannah River Technology Center

\section{LIST OF TABLES}

Table I. Coordinates for Monitoring Sites .................................................. 4

Table II. Descriptions of Data Nomenclature..............................................................5 


\section{INTRODUCTION}

During the period from May 2000 to September 2001, ocean surface water temperature data was collected at the Pilgrim Nuclear Power Station near Plymouth, MA (Figure 1). This effort was led by the Savannah River Technology Center (SRTC) with the assistance of a local sub-contractor, Marine BioControl Corporation of Sandwich, MA. Permission for setting up the monitoring system was granted by Entergy Corporation, which owns the plant site. This work was done in support SRTC's ground truth mission for the US Department of Energy's Multispectral Thermal Imager (MTI) satellite (Garrett, et al, 1999). Data described in this report are available from the authors (contact information provided at the end of report).
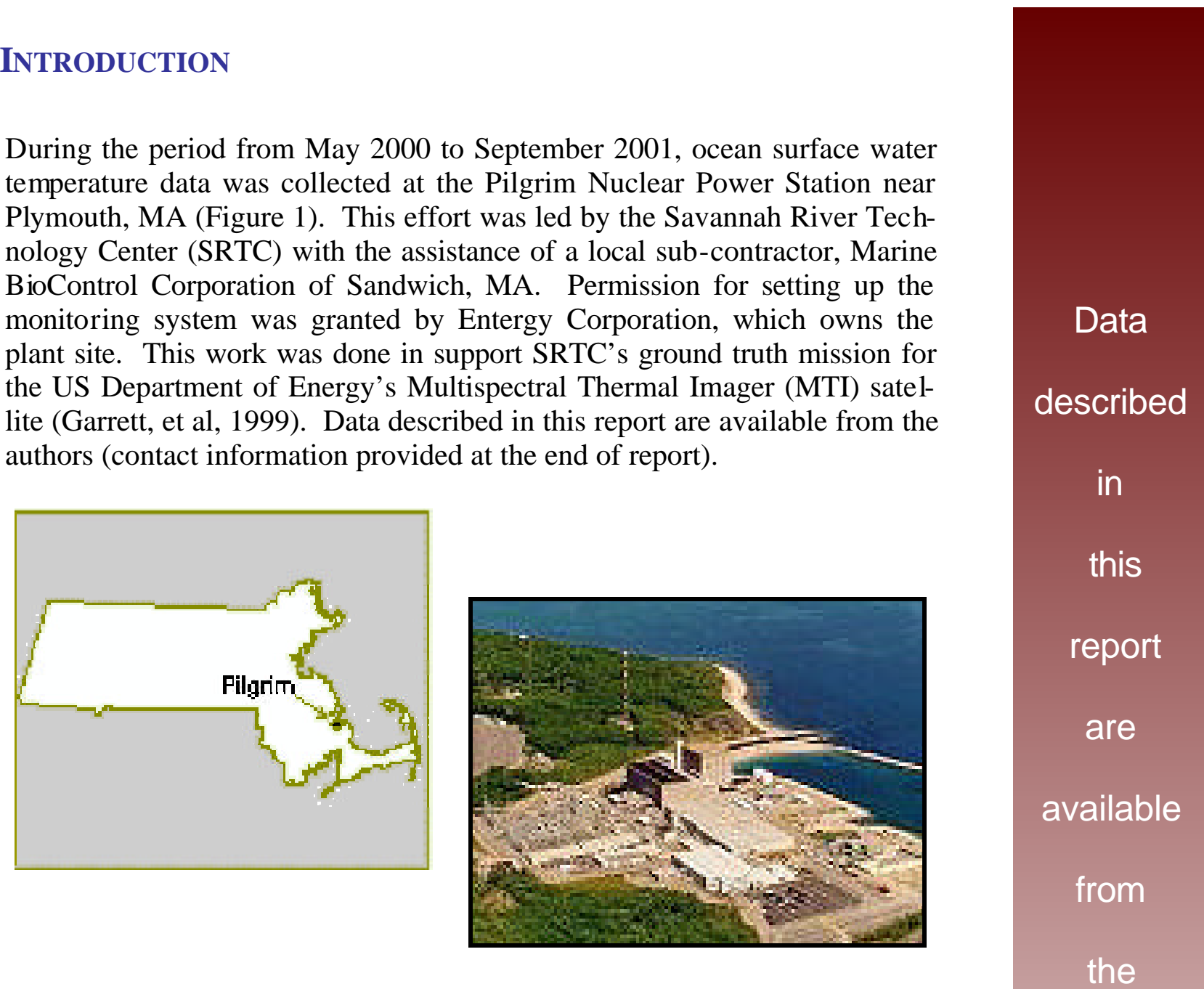

Figure 1. The Pilgrim Nuclear Power Station near Plymouth, MA.

\section{authors.}

\section{Surface Water Temperature Measurements}

Six monitoring long-term monitoring sites are shown as letters A through $\mathrm{F}$ in Figure 2. Sites A and B were located in the partially protected plant water intake bay. Sites C, D, and E were located in the open Atlantic Ocean, a short distance beyond the warm-water discharge where site $\mathrm{F}$ was located. The general reasoning behind the selection of these sites was to obtain data that captured the greatest temperature extremes near the plant (intake and discharge) and the location of the warm-water discharge plume in the Atlantic Ocean. 


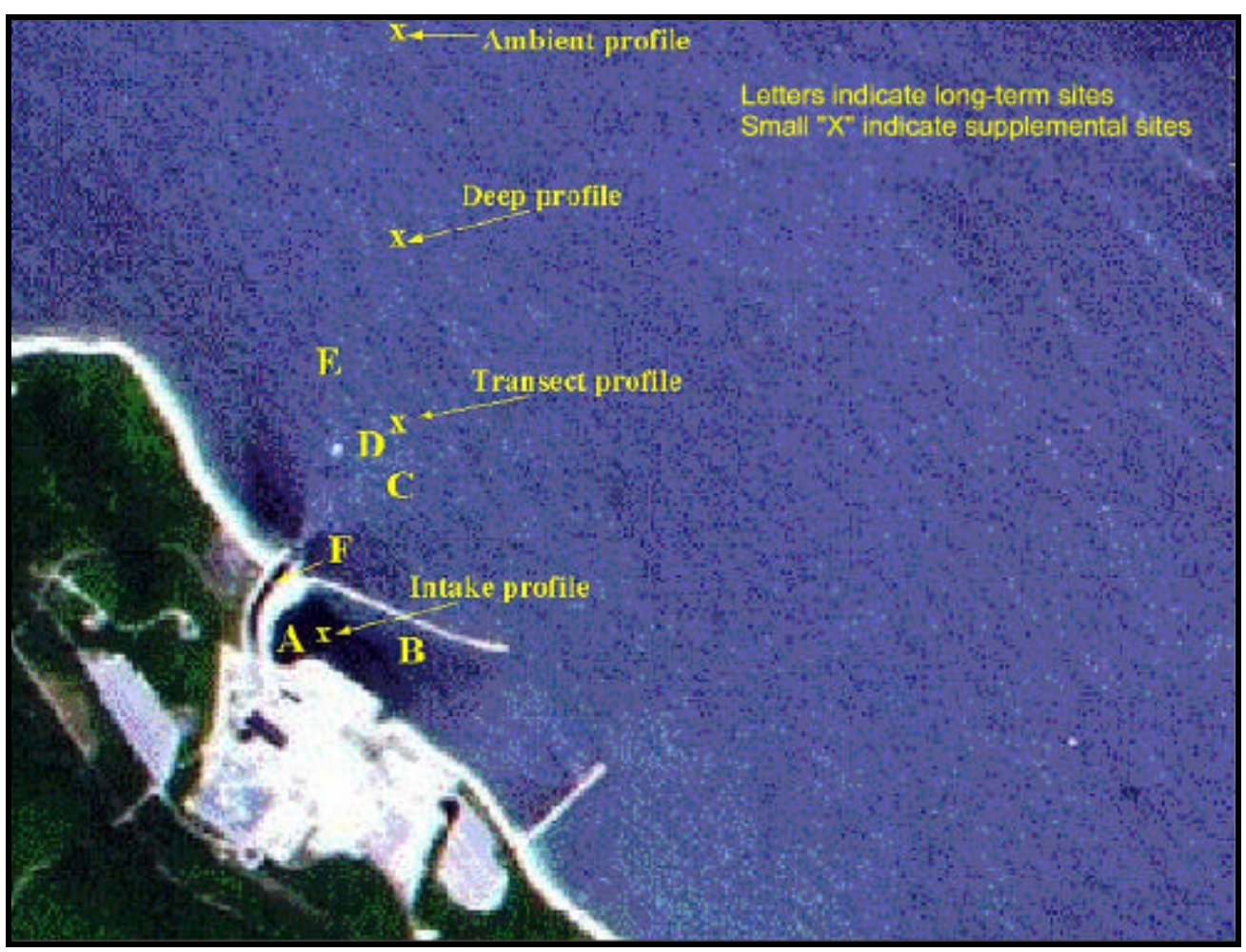

Figure 2. Monitoring site locations.

Temperature measurements were made with the StowAway® TidbiT ${ }^{\circledR}$ (Figure 3 ) manufactured by Onset Computer (www.onsetcomputer.com). The sensors used for surface water measurements (Sites A, B, C, D and E) were suspended approximately $30 \mathrm{~cm}$ below (Figures 4 and 5) anchored buoys (Figure 5). Similarly, the sensors used for the supplemental profile measurements were attached to anchor mooring line at various depths (see Table I). Measurements taken at Site $\mathrm{F}$ were made by attaching a protective case with the TidbiT® to a permanent steel beam within the discharge canal.

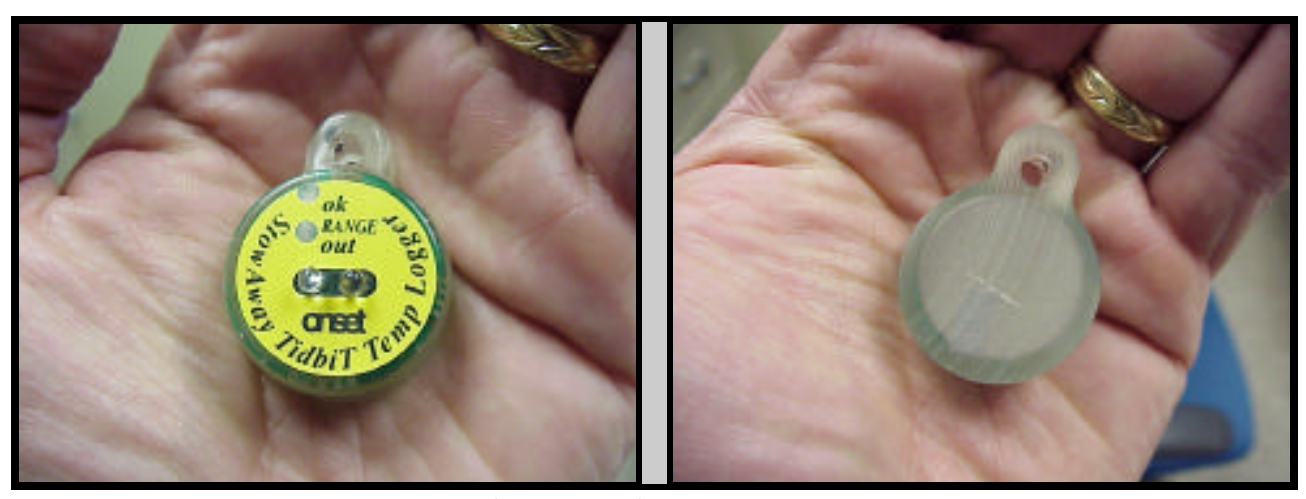

Figure 3. The StowAway® TidbiT ${ }^{\circledR}$ (front view, left, and rear view, right). 


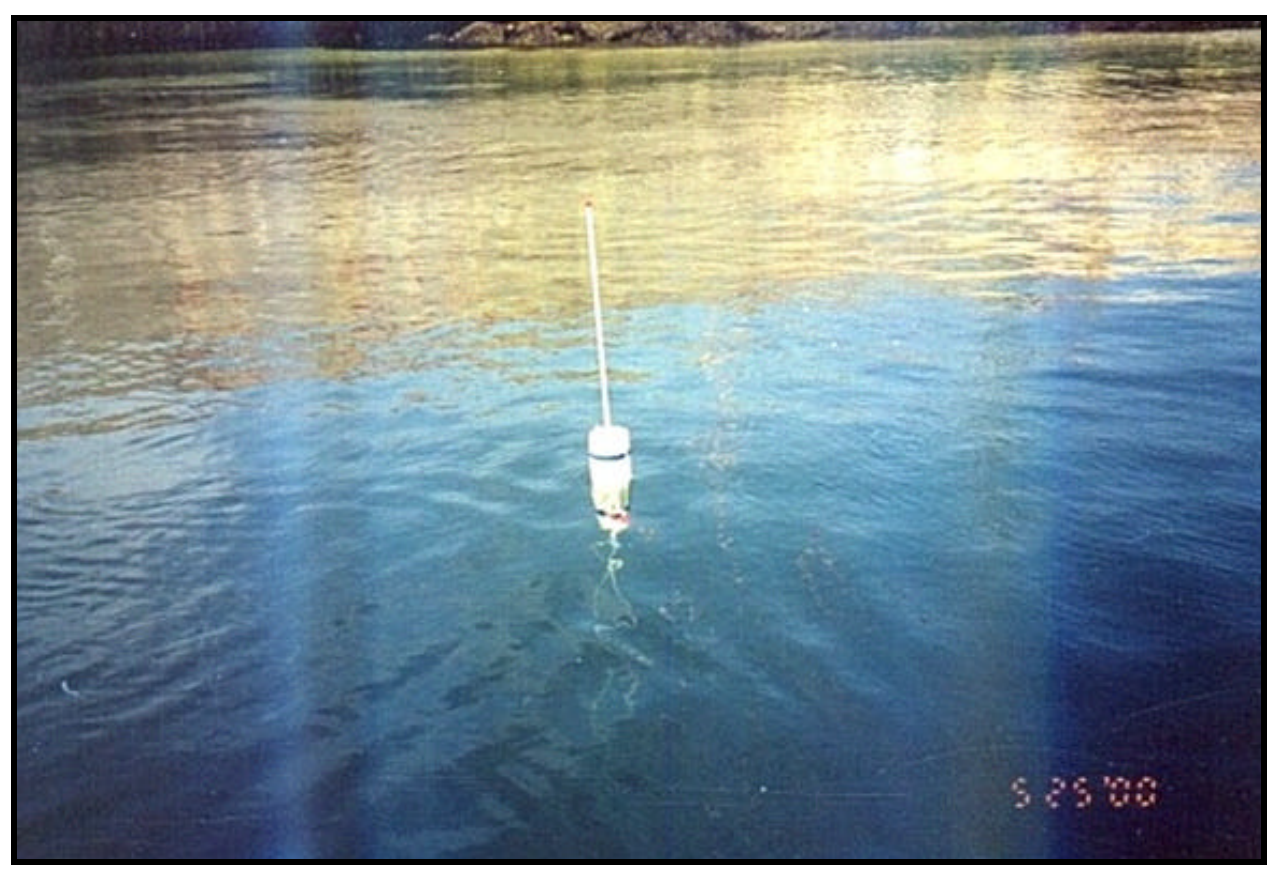

Figure 4. TidbiT® suspended below buoy.

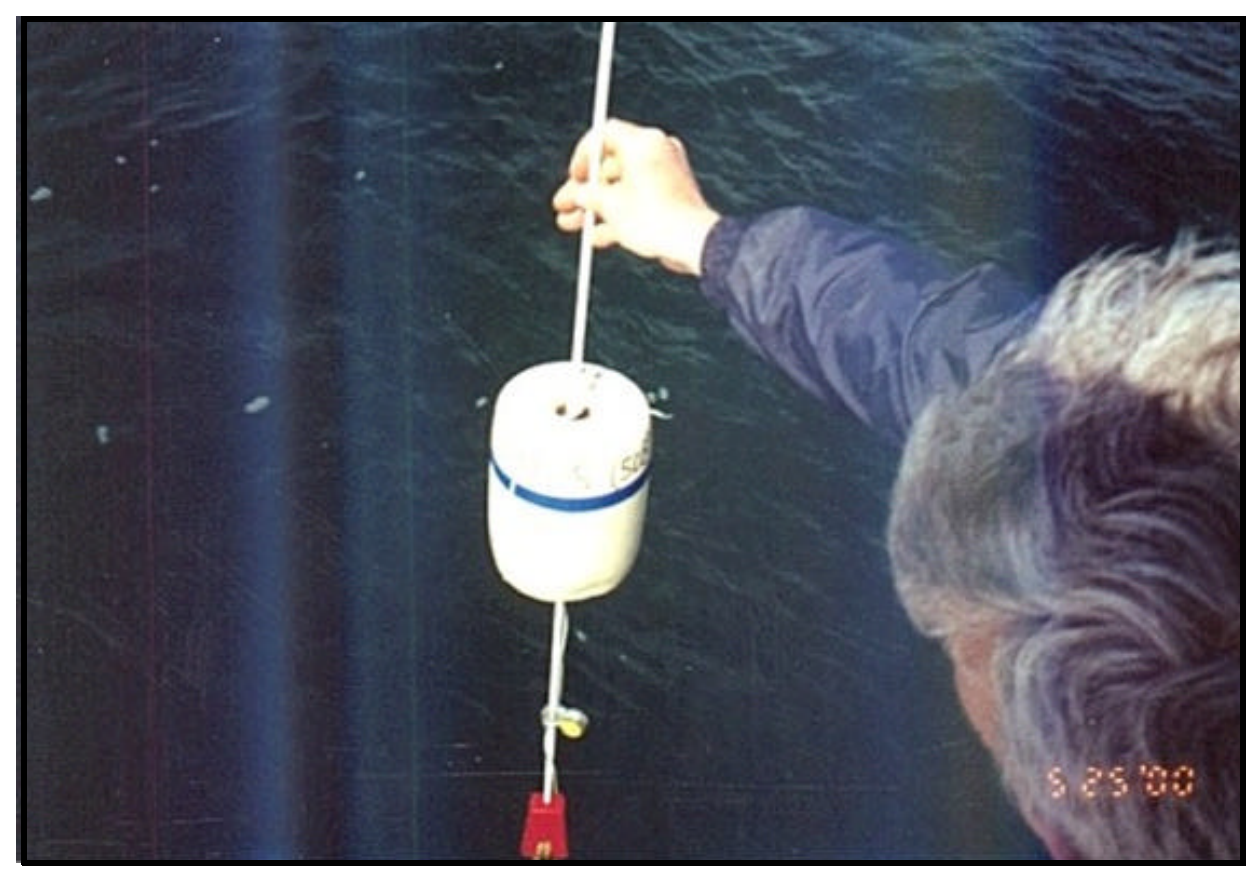

Figure 5. Deployed buoy (near intake at Site A). 
Supplemental data were collected at four additional sites, shown as " $x$ " in Figure 2, over the period from mid-August 2001 to early September 2001. The objective was to collect temperature data at different depths, or profiles, within the water intake bay ("Intake" profile), near site "D" ("Transect" profile), just beyond site "D" ("Deep" profile), and at a site ("Ambient" profile) presumably unaffected by the warm-water discharge and well beyond the other sites. Measurement depths ranged from just a few centimeters below the water's surface down to the ocean bottom. Part of this period occurred when the plant was not operating and continued when the plant was restarted. Coordinates for all monitoring sites are provided in Table I.

Table I. Coordinates for Monitoring Sites

Site

A

B

C

D

E

$\mathrm{F}$

Intake profile

Transect profile

Deep profile

Ambient profile

\section{Coordinates (WGS-84)}

$\mathrm{N} 41^{\circ} 56.76^{\prime}, \mathrm{W} 70^{\circ} 34.75^{\prime}$

$\mathrm{N} 41^{\circ}$ 56.77', W 70 34.62 '

$\mathrm{N} 41^{\circ} 56.91^{\prime}$. W $70^{\circ} 34.63^{\prime}$

$\mathrm{N} 41^{\circ} 56.95^{\prime}$, W $70^{\circ} 34.68^{\prime}$

$\mathrm{N} 41^{\circ} 56.98^{\prime}, \mathrm{W} 70^{\circ} 34.73^{\prime}$

$\mathrm{N} 41^{\circ} 56.801$ ', W $70^{\circ} 34.780^{\prime}$

$\mathrm{N}^{\circ} 41$ 56.762', $\mathrm{W}^{\circ} 7034.704$ '

$\mathrm{N}^{\circ} 41$ 56.948', W० 7034.676 '

$\mathrm{N}^{\circ} 41$ 57.068', W० $7034.675^{\prime}$

$\mathrm{N}^{\circ} 41$ 57.313', W० 7034.739 '

Additionally, Pilgrim personnel supplied plant operating and meteorological data for the entire period of study. These data were merged with the water temperature data and are stored in a spreadsheet (see the "Data Description" section of this document).

\section{TIME STAMPS}

Data were collected with time stamps corresponding to local Eastern (Standard or Daylight) Time. Time stamps associated with the Tidbits ${ }^{\circledR}$ were used as the time stamp for all data. Given this requirement, the me teorological and plant operating data that most closely corresponded with the time stamp of the Tidbit ${ }^{\circledR}$ data were 
merged as though they had an identical time stamp. In the majority of cases, the actual difference between the various data types was less than 10-15 minutes making relevant comparisons appropriate.

Plant operating data were sub-sampled to correspond to the water temperature data, and the meteorological data are reported as hourly averages.

\section{DATA DESCRIPTION}

The following table summarizes the headings in the file called QA_Pfull.xls (available from the authors), which contains surface water temperature data, meteorological data, and plant operating data.

Table II. Description of Data Nomenclature

\begin{tabular}{|c|c|}
\hline \multicolumn{2}{|r|}{ SURFACE WATER TEMPERATURES } \\
\hline Name & (All temperatures ${ }^{\circ} \mathrm{C}$ ) \\
\hline A & $\begin{array}{l}\text { Surface water temperature at location A near the plant water } \\
\text { intake }\end{array}$ \\
\hline B & $\begin{array}{l}\text { Surface water temperature at location B to the northeast of the } \\
\text { plant intake but within the protected area }\end{array}$ \\
\hline $\mathrm{C}$ & $\begin{array}{l}\text { Surface water temperature at location } \mathrm{C} \text { to the southeast of the } \\
\text { discharge flow into the open ocean }\end{array}$ \\
\hline $\mathrm{D}$ & $\begin{array}{l}\text { Surface water temperature at location D to the east of the dis } \\
\text { charge flow into the open ocean }\end{array}$ \\
\hline $\mathrm{E}$ & $\begin{array}{l}\text { Surface water temperature at location } \mathrm{E} \text { to the northeast of the } \\
\text { discharge flow into the open ocean }\end{array}$ \\
\hline $\mathrm{F}$ & $\begin{array}{l}\text { Discharge water temperature at location } \mathrm{F} \text { in the plant discharge } \\
\text { canal }\end{array}$ \\
\hline
\end{tabular}

\section{HOURLY METEOROLOGICAL DATA}

Name Description

WD220 Wind direction (degrees) at $220 \mathrm{ft}$

WS220 Wind speed (mph) at $220 \mathrm{ft}$

WD220/33 Wind direction (degrees) at $33 \mathrm{ft}$ on the $220 \mathrm{ft}$ tower

T220/33

Temperature $\left({ }^{\circ} \mathrm{F}\right)$ at $33 \mathrm{ft}$ on the $220 \mathrm{ft}$ tower

DELTA220 Temperature difference (Delta-T) $\left({ }^{\circ} \mathrm{F}\right)$ on the $220 \mathrm{ft}$ tower

WD160 Wind direction (degrees) at $160 \mathrm{ft}$

WS160 Wind speed (mph) at $160 \mathrm{ft}$ 


\section{HOURLY METEOROLOGICAL DATA}

$\underline{\text { Name }}$

WD220

WS220

WD220/33

WS220/33

T220/33

DELTA220

WD160

WS160

WD160/33

WS160/33

T160/33

DELTA160

\section{$\underline{\text { Description }}$}

Wind direction (degrees) at $220 \mathrm{ft}$

Wind speed (mph) at $220 \mathrm{ft}$

Wind direction (degrees) at $33 \mathrm{ft}$ on the $220 \mathrm{ft}$ tower

Wind speed (mph) at $33 \mathrm{ft}$ on the $220 \mathrm{ft}$ tower

Temperature $\left({ }^{\circ} \mathrm{F}\right)$ at $33 \mathrm{ft}$ on the $220 \mathrm{ft}$ tower

Temperature difference (Delta-T) $\left({ }^{\circ} \mathrm{F}\right)$ on the $220 \mathrm{ft}$ tower

Wind direction (degrees) at $160 \mathrm{ft}$

Wind speed (mph) at $160 \mathrm{ft}$

Wind direction (degrees) at $33 \mathrm{ft}$ on the $160 \mathrm{ft}$ tower

Wind speed (mph) at $33 \mathrm{ft}$ on the $160 \mathrm{ft}$ tower

Temperature $\left({ }^{\circ} \mathrm{F}\right)$ at $33 \mathrm{ft}$ on the $160 \mathrm{ft}$ tower

Temperature difference (Delta-T) $\left({ }^{\circ} \mathrm{F}\right)$ on the $160 \mathrm{ft}$ tower

\section{PLANT OPERATING DATA READINGS}

Name

$\underline{\text { Description }}$

C003T

Reactor power (MW)

$\mathrm{C} 017 \mathrm{~T}$

Reactor power (MW)

CWSO02

Inlet temperature $\left({ }^{\circ} \mathrm{F}\right)$

CWS004

Inlet temperature $\left({ }^{\circ} \mathrm{F}\right)$

CWS006

Discharge temperature $\left({ }^{\circ} \mathrm{F}\right)$

CWS008

Discharge temperature $\left({ }^{\circ} \mathrm{F}\right)$

CWS518

Reactor operating status (RUN/OFF)

CWS520

Reactor operating status (RUN/OFF) 


\section{SUPPLEMENTAL WATER TEMPERATURE DATA}

Name Description $\quad$ (All temperatures ${ }^{\circ} \mathrm{C}$ )

A $10 \mathrm{~cm}$

A $3 m$

A5.5m

A8m

$\mathrm{A} 10.5 \mathrm{~m}$

A13m

$\mathrm{DP} 10 \mathrm{~cm}$

DP1.5m

DP3m

DP4.5m

DP6m

DP7.5m

DP9m

DP10.5m

$\mathrm{I} 10 \mathrm{~cm}$

$\mathrm{I} 1.5 \mathrm{~m}$

$\mathrm{I} 3 \mathrm{~m}$

$\mathrm{I} 4.5 \mathrm{~m}$

$\mathrm{I} 6 \mathrm{~m}$

$\mathrm{I} 7.5 \mathrm{~m}$

$19 \mathrm{~m}$

TD10cm

TD1m

TD2m

TD3m

TD4m

TD5m

TD6m

TD7m

TD8m
"Ambient" profile at the $10 \mathrm{~cm}$ level

"Ambient" profile at the $3 \mathrm{~m}$ level

"Ambient" profile at the $5.5 \mathrm{~m}$ level

"Ambient" profile at the $8 \mathrm{~m}$ level

"Ambient" profile at the $10.5 \mathrm{~m}$ level

"Ambient" profile at the $13 \mathrm{~m}$ level (on the sea floor)

"Deep Profile" at the $10 \mathrm{~cm}$ level

"Deep Profile" at the $1.5 \mathrm{~m}$ level

"Deep Profile" at the $3 \mathrm{~m}$ level

"Deep Profile" at the $4.5 \mathrm{~m}$ level

"Deep Profile" at the $6 \mathrm{~m}$ level

"Deep Profile" at the $7.5 \mathrm{~m}$ level

"Deep Profile" at the $9 \mathrm{~m}$ level

"Deep Profile" at the $10.5 \mathrm{~m}$ level

"Intake" profile at the $10 \mathrm{~cm}$ level

"Intake" profile at the $1.5 \mathrm{~m}$ level

"Intake" profile at the $3 \mathrm{~m}$ level

"Intake" profile at the $4.5 \mathrm{~m}$ level

"Intake" profile at the $6 \mathrm{~m}$ level

"Intake" profile at the $7.5 \mathrm{~m}$ level

"Intake" profile at the $9 \mathrm{~m}$ level

"Transect" profile near the D-buoy at the $10 \mathrm{~cm}$ level

"Transect" profile near the D-buoy at the $1 \mathrm{~m}$ level

"Transect" profile near the D-buoy at the $2 \mathrm{~m}$ level

"Transect" profile near the D-buoy at the $3 \mathrm{~m}$ level

"Transect" profile near the D-buoy at the $4 \mathrm{~m}$ level

"Transect" profile near the D-buoy at the $5 \mathrm{~m}$ level

"Transect" profile near the D-buoy at the $6 \mathrm{~m}$ level

"Transect" profile near the D-buoy at the $7 \mathrm{~m}$ level

"Transect" profile near the D-buoy at the $8 \mathrm{~m}$ level 


\section{QUALITY ASSURANCE}

Data quality assurance was performed on all surface water temperature measurements. The first source of identifying unusable data was via a maintenance log kept by Marine BioControl. Then, time series plots of data were reviewed for obvious outliers or other problematic data. Problematic data were deleted and appear as blanks within the data files. Another source of missing (blank) data occurred during the March 3-20, 2001 period when the A, B, C, D, and E sensors were removed due an approaching nor'easter.

\section{Example Data Plots}

The following figures (6-12) show examples of data plotted from the quality assured spreadsheet (QA_Pfull.xls). Items of interest are noted on the plots.

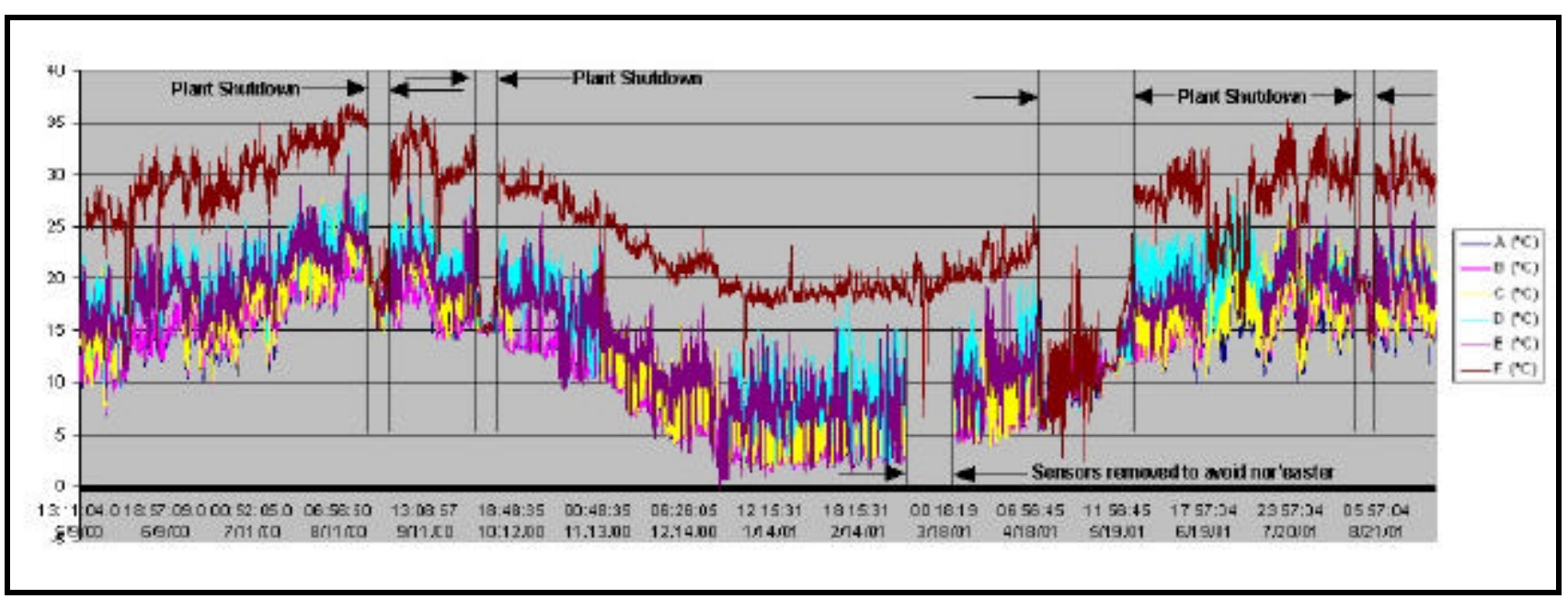

Figure 6. Time series plot of water temperature data collected during the May 2000-September 2001 period. 


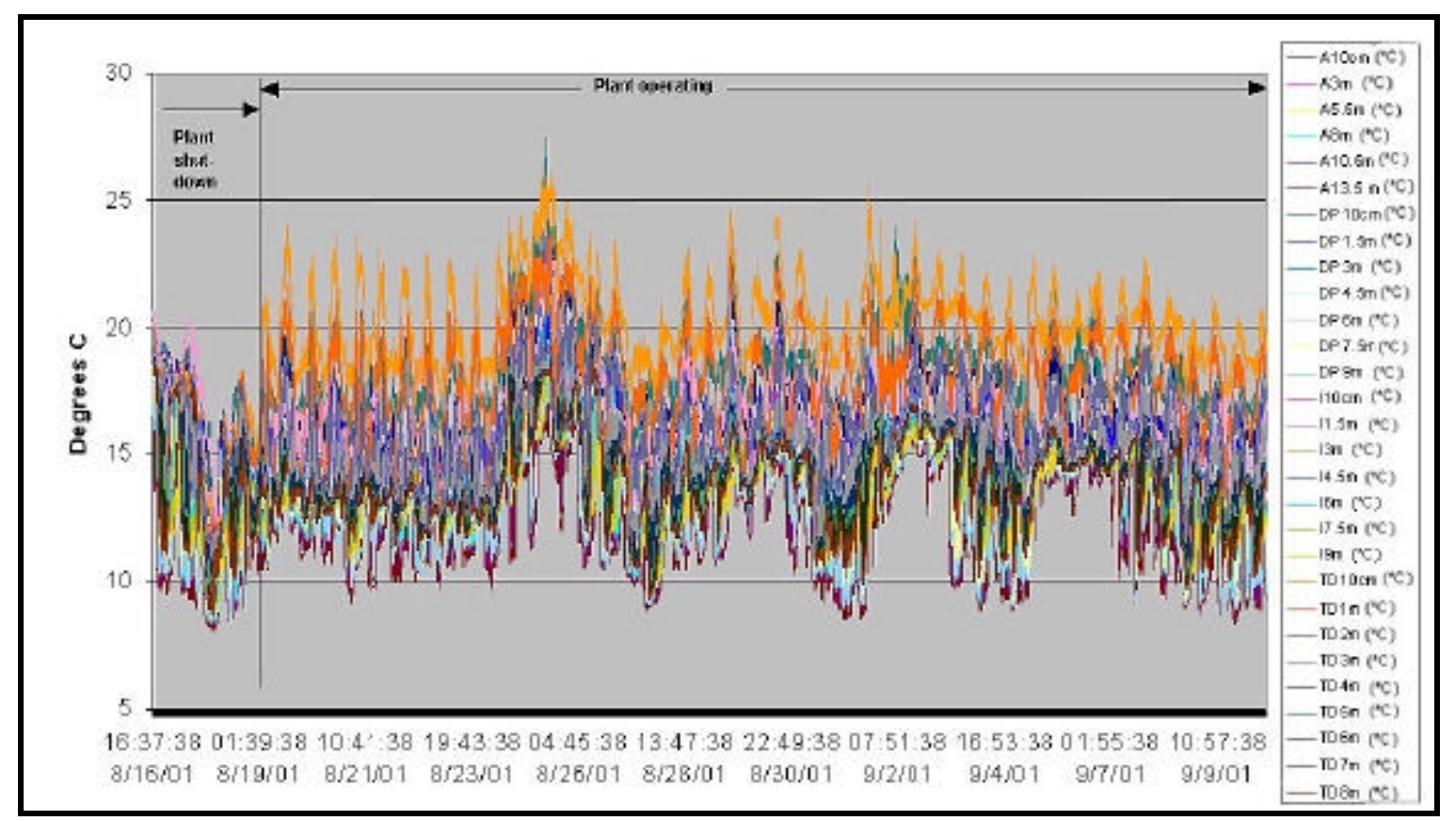

Figure 7. Supplemental water temperature measurements during the August-September, 2001 period. Note the differences between the period when power was not being generated (near the beginning of the plot) and the period when the plant was generating power.

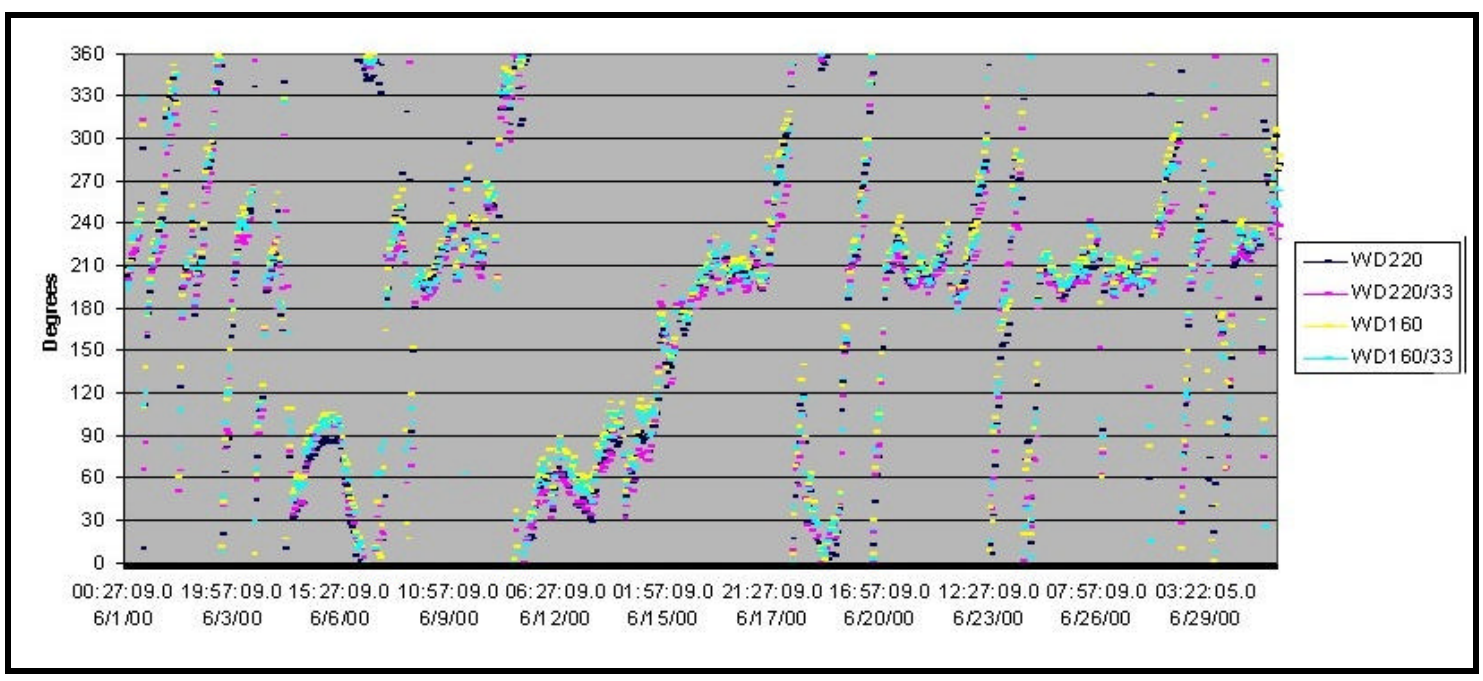

Figure 8. Example of wind direction data collected at $220 \mathrm{ft}$ and $33 \mathrm{ft}$ on Pilgrim's $220 \mathrm{ft}$ tower and at $160 \mathrm{ft}$ and $33 \mathrm{ft}$ on Pilgrim's $160 \mathrm{ft}$ tower.

Data are from June 2000. 
WSRC-TR-2002-00373

Final MTI Data Report: Pilgrim Nuclear Station (U)

Savannah River Technology Center

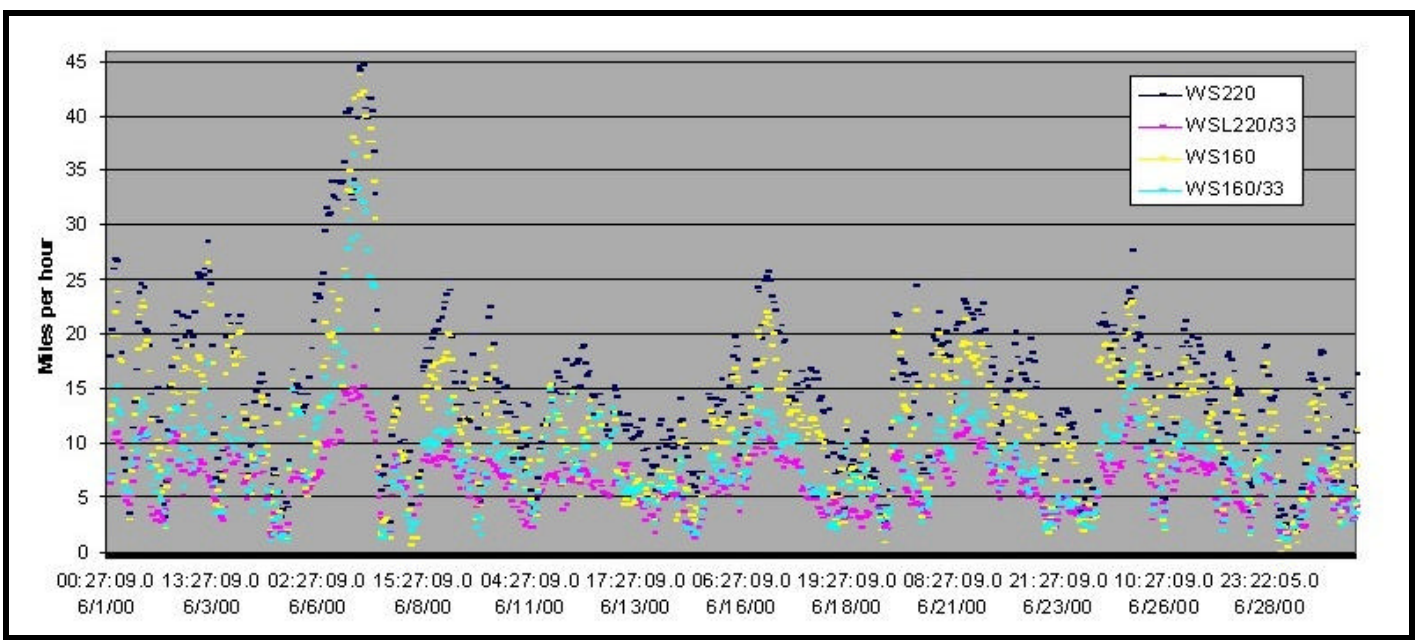

Figure 9. Example of wind speed data collected at $220 \mathrm{ft}$ and $33 \mathrm{ft}$ on Pilgrim's $220 \mathrm{ft}$ tower and at $160 \mathrm{ft}$ and $33 \mathrm{ft}$ on Pilgrim's $160 \mathrm{ft}$ tower. Data are from June 2000.

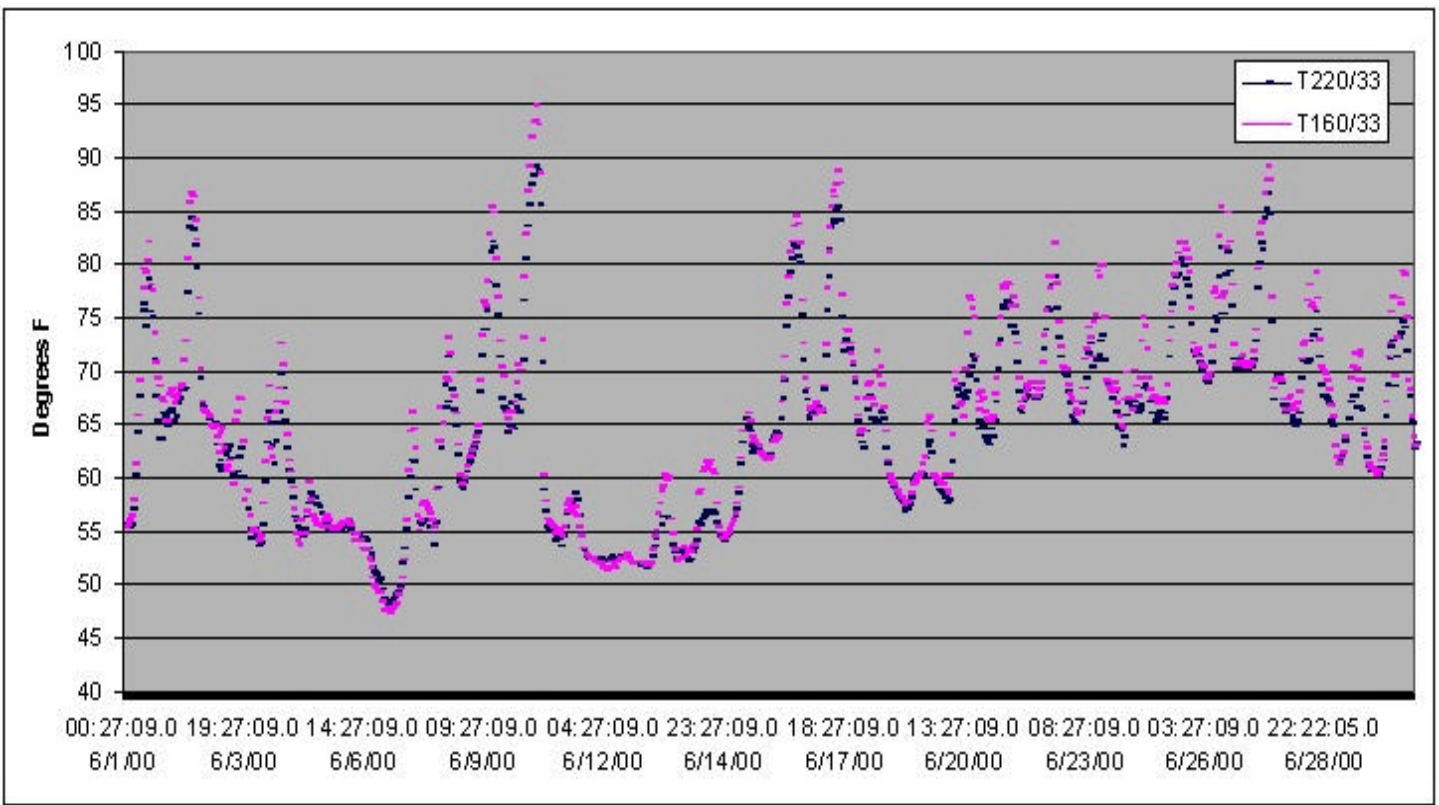

Figure 10. Example of air temperature data collected at $33 \mathrm{ft}$ on Pilgrim's $220 \mathrm{ft}$ and $160 \mathrm{ft}$ tower sites in June 2000. 


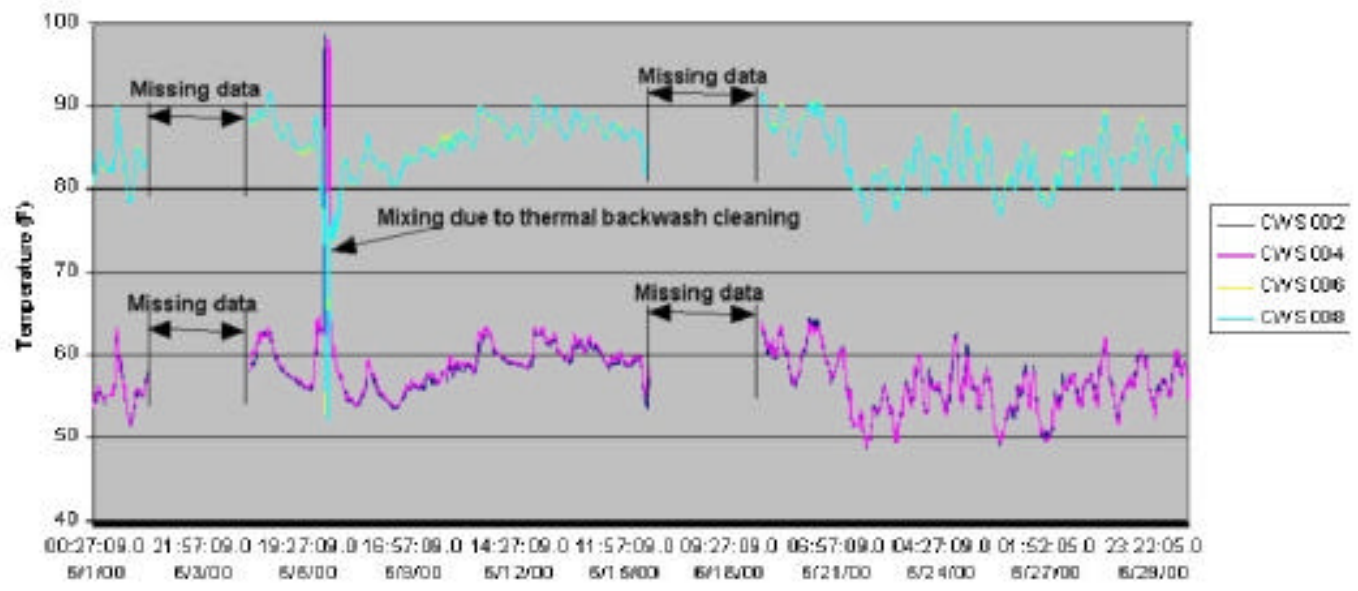

Figure 11. Example of plant water intake and outfall temperatures for June 2000. Note the mixing that occurred during the thermal-backwash cleaning event on June 7, 2000.

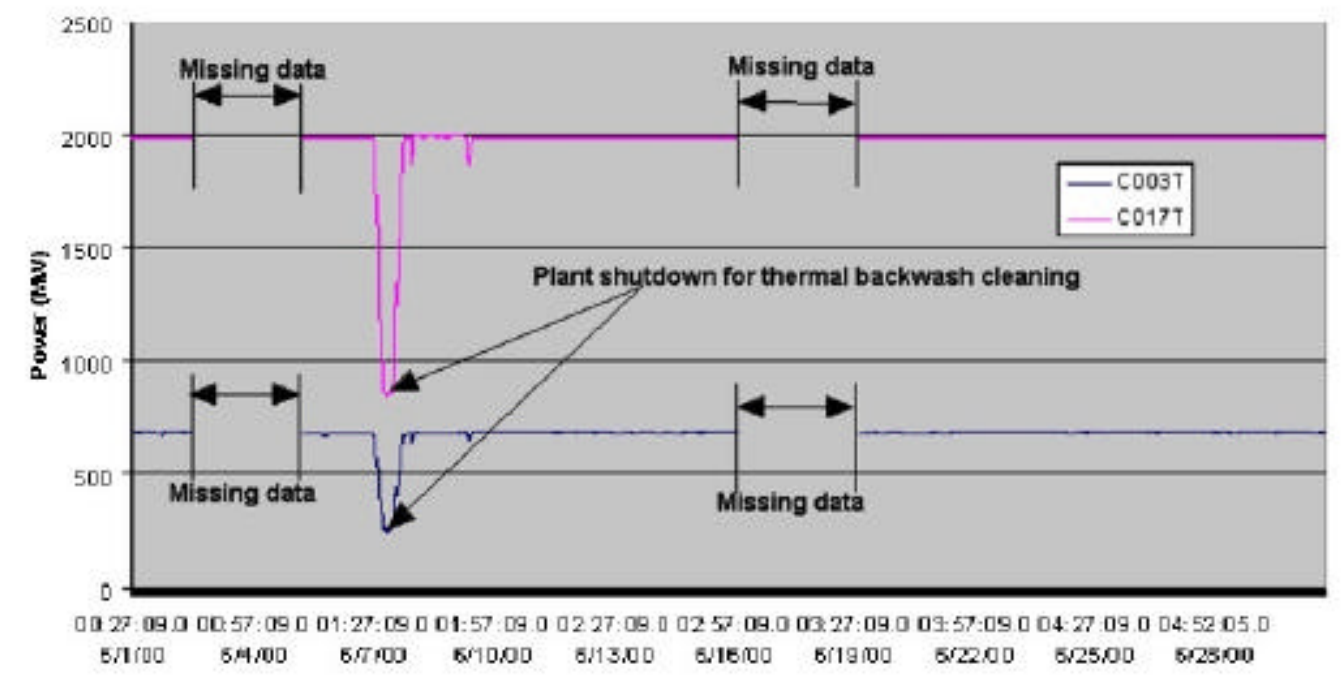

Figure 12. Example of plant power data for June 2000. Note the brief shutdown during the thermal-backwash cleaning event on June 7, 2000. 


\section{ACKNOWLEDGEMENTS}

of Sandwich, MA for their tireless work in obtaining water temperature data and to Ken Sejkora of Entergy for providing plant operating and meteorological data. Thanks also to Kuo-Fu Chen of SRTC for assisting with data quality assurance.

\section{REFERENCES}

1

Villa-Aleman, 1999: Ground-Truth Measurements Plan for the Multispectal Thermal Imager (MTI) Satellite. WSRC-TR-99-00455. Westinghouse Savannah River Company, Aiken, SC. 